\title{
Loyalty Programme Roulette: The Loyal, The Committed, And The Polygamous
}

Michael Noel du Toit, University of South Africa, South Africa

Michael Colin Cant, Ph.D., University of South Africa, South Africa

\begin{abstract}
Loyalty programmes have two main aims, firstly to gather consumer data and secondly to create or maintain loyal behaviour amongst their customers. The aim of this study was to investigate the results of a loyalty programme and evaluate its effectiveness in encouraging loyal behaviour amongst members. In order to achieve this objective, a comparison was made between the loyal behaviour of members and non-members of a loyalty programme at a single clothing retailer by means of a structured questionnaire. Respondents were questioned about their perceived commitment to the retailer, their current purchase behaviour and their anticipated future behaviour with regards to long-term loyalty towards the retailer. In keeping with traditional loyalty theory, respondents were also asked to report on their willingness to recommend the retailer to their peers. The study showed that there is very little empirical evidence to support increased loyal behaviour as a direct result of loyalty programme membership. Evidence was presented however, that strongly supports a link between customers' commitment to the retailer and their loyal behaviour regardless of their membership status.
\end{abstract}

Keywords: Loyalty Programmes; Customer Loyalty; Commitment

\section{INTRODUCTION}

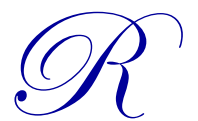

etail loyalty programmes are fast becoming ubiquitous with more than 2 billion loyalty programme memberships in the Unites States alone (Sisolak 2012; Capizzi, Ferguson and Cuthbertson 2004). Researchers have long argued for and against the use of loyalty programmes to create and or maintain loyal behaviour amongst customers (Dowling and Uncles 1997; Wu, Hai-Chen and Chung-Yu 2012). While most articles dealing with loyalty programmes cite more benefits of loyalty programmes than there are drawbacks, there are a growing number of research papers that are increasingly negative about the long-term effects of loyalty programmes. In this study the benefits of loyalty programmes are weighed up against the most common criticisms against these programmes before empirical evidence is presented to prove that membership of a loyalty programmed does not necessarily result in loyal behaviour by consumers. The theory states that loyalty programmes are introduced in order to create loyal behaviour and gather data about customers. In this study we compare the loyal behaviour of members versus non-members of a loyalty programme and find that there is very little empirical evidence to support increased loyal behaviour as a result of membership. Members are marginally more committed to the retailer, but there is no significant difference in willingness to recommend or desire to purchase more from the retailer in the future.

\section{LITERATURE REVIEW}

The worldwide economic down turn has placed renewed pressures on all organisations, including retailers to secure the support and loyalty of their customers. For the past few years the focus has been on green marketing, the environment and social programmes, but recently the emphasis has shifted back to service quality and customer loyalty. Companies are realising anew that the "customer is king" and that if you want to survive the "king" must be satisfied. Consequently organisations, including retailers, have embarked on a drive for loyalty from their customers. The reasoning is that if a customer is roped into a loyalty programme with the company the company can rely on his/her loyal support and expect loyal behaviour. The problem is that many competitive organisations are thinking 
the same way and the questions that arise are - "Will the loyalty programme members be committed to my company?"; "Will the members purchase more from my company?" and "Will the members recommend my company to others?" In order to address these questions, this literature review will begin with a short background to the concept of customer loyalty; will introduce the benefits of loyalty programmes; and will conclude with some criticisms against loyalty programmes.

\section{Customer loyalty}

Loyalty as a noun is defined as "...the quality of being faithful [act] in your support of somebody or something [object]" (Oxford 2012, sv Loyalty). This is a very broad definition - one that allows the use of the word loyalty in a wide range of applications and settings, such as in brand loyalty, retail loyalty and organisational loyalty amongst others -all different types of loyalty that represent the commitment to the organisation that the marketer is looking for. A loyal customer can be defined as one who has an emotional attachment to an organisation, acts positively towards the organisation by purchasing repeatedly from the organisation over a certain period of time and recommends the organisation to others including friends and colleagues (Griffin 2002; Hallberg 2004; Reichheld 2006). Loyal customers are therefore important to the organisation as both a source of revenue and a marketing tool for recommending the organisation. Loyalty programmes are designed to create loyal customers. While there may be different opinions as to what loyalty or a loyal customer is, most marketing academics agree there are fundamental benefits of having loyal customers. These benefits include the fact that it provides the organisation with a competitive advantage, it can increase profitability; and loyal customers become brand advocates for the organisation. Each of these advantages is briefly addressed:

Competitive advantages of loyalty

Having loyal customers provides the organisation with a number of competitive advantages (Allaway, Gooner, Berkowitz and Davis 2006; Griffin 2002; Kumar 2006; Yi and Jeon, 2003) which can be cited as follows:

- Loyal customers consciously select the organisation again and again, thereby reducing the market share of competitors.

- Loyal customers are less price-sensitive and, therefore, will not react to lower price offers from competitors.

- Loyal customers allow the organisation the opportunity to match a competitive offering or to correct a service failure before defecting.

- Having loyal customers reduces the marketing costs of acquiring new customers.

- customer loyalty serves as a deterrent that prevents customers from easily changing to a competitive organisation or brand.

Impact of loyalty on organisational profitability

Griffin (2002) notes a number of ways that customer loyalty can increase organisational profitability. The main ways identified are:

- A reduction in marketing costs. The costs of marketing to a loyal customer may be reduced owing to the fact that retaining a customer is cheaper than acquiring a new one. Customer acquisition implies more promotion and more customer education, which are more expensive than customer maintenance. When an organisation is spending less on marketing costs, it can, instead, invest more into improving the product quality or employee satisfaction (Griffin 2002; Allaway et al 2006).

- Lower transaction costs. Loyal customers tend to be less price-sensitive and, therefore, not prone to consider the marketing efforts of competitors (Allaway et al 2006). Also, when selling to a loyal customer there is no need for extended negotiations with the customer regarding price, delivery, packaging etcetera, and rather a focus on maintaining and expanding the relationships. This lowers the transaction costs over time. 
- $\quad$ Reduced customer acquisition costs. Acquiring new customers after unhappy customers have defected is expensive as it requires intensive marketing efforts. By keeping current customers happy, and having them loyal to the organisation means a reduction in funds needed that would normally have been spend on acquiring new customers.

- $\quad$ Increased cross selling. Because loyal customers are more familiar with the organisation and its product mix and have developed a trusting relationship, cross selling of additional items becomes easier. When customers purchase more from the organisation, the organisation has a larger share of the customer's wallet, which further strengthens the relationship and increases the cost of defection to the customer.

- $\quad$ Reduced failure costs. Over the lifetime of a relationship with the customer, both the organisation and the customer learn to act in certain ways and expect certain levels of service or respect. This reduces the costs of errors or failures in service delivery over time.

- Increased word-of-mouth. The definition of customer loyalty implies increased referral of the organisation to friends or colleagues. Word-of-mouth can lead to an increase in the number of customers, without additional marketing costs (Griffin 2002; Gomez, Arranz and Cillan 2006).

The impact that loyalty may have on the profitability of an organisation must not be under estimated. In the same way it must be recognised that loyalty can only be as strong as the most recent interaction with the customer if not nurtured and protected by the organisation

Loyalty and Brand advocacy

Reichheld (2006) believes that a loyal customer will be an advocate of that particular organisation. Blasberg, Vishwanath and Allen (2008) support Reichheld (2006) by arguing that the most useful way to measure customer loyalty is to ask the question: "How likely are you to recommend this organisation to a friend or colleague?" customers who answer that they are highly likely to recommend the organisation to a friend or colleague are called "promoters" and represent the highest level of loyalty in Reichheld's Net Promoter Score (NPS) (Reichheld 2006).

Word-of-mouth communications and, more specifically, advocacy by customers, are valuable to an organisation because of the following reasons suggested by Keiningham, Aksoy, Cooil and Andreassen (2008) and Steffes and Burgee (2008):

- Customer advocacy costs virtually nothing.

- Due to technology, advocacy no longer occurs on a person-to-person basis but rather on a person-to-world basis.

- $\quad$ Customer advocacy is automatically more credible to a recipient than organisation-sponsored marketing communication.

\section{Retail loyalty programmes}

Over the years many retailers have been investing huge amounts of money in loyalty programmes and the establishing of a loyal customer base. Offering a loyalty programme is generally regarded as one of the best ways to establish and nurture loyal customers (Anon1 2012; Polevoi 2012). Loyalty programmes have become strategic tools in the marketing effort of companies as they battle to differentiate themselves from their competitors and vie for the support and acceptance of their company or brand amongst customers. Loyalty per se, is often measured by the customer's willingness to recommend the organisation to friends or colleagues; or by the return patronage (repeat buying behaviour) demonstrated by the customer (Griffin 2002; Reichheld 2006) while loyalty programmes are generally designed with the expectation that enrolling more customers into the programme will result in more referrals and more return patronage or, at the very least, an expression of willingness to return to the organization. In the end the aim stays to generate revenue and increase profitability. 


\section{The goals of loyalty programmes}

In the early years of loyalty programmes, the main reasoning behind the launching of the programmes may have been to gather information on customers and their purchase behaviour. It was hoped that with this information the organisation could fine tune their marketing actions and better meet the needs and demands of the customers. Secondly, but equally important was the objective to increase loyal behaviour from customers - and in so doing revenue. Banasiewicz (2005) describes the main goal of a loyalty programme as being one of two possibilities: a net increase in revenue, or an increase in profitability. If the goal of the loyalty programme is to increase revenue, then the formation of the loyalty programme would have to focus on volume discounts and cash rebates, thus influencing the reward structure. If the goal of the loyalty programme is to increase profitability, then the loyalty programme would have to be structured differently in order to encourage repurchase and discourage price-sensitivity.

When looking at these goals in perspective it is clear that they are aligned with the overall marketing concept of customer satisfaction and the generation of a profit. This by implication means that they are in line with the organisations' strategic goals and objectives. In this context, Banasiewicz (2005) summarises potential goals of loyalty programmes as:

- $\quad$ Aimed at reducing consumer turnover,

- $\quad$ Aimed at growing the organisation's market share,

- $\quad$ Aimed at encouraging more sales from existing consumers,

- $\quad$ Aimed at providing data and insights into consumer behaviour,

- $\quad$ Aimed at encouraging long-term relationships with consumers and finally

- $\quad$ Aimed at increasing profitability.

It would appear from the discussion that the benefits of loyal customers and the lofty objectives of loyalty programmes are above reproach, but it is also true that there are some criticisms levelled at these types of programmes. Some of these are listed below.

\section{Criticisms against loyalty programmes}

The literature is overwhelming in its support of loyalty programmes as a tool to create and maintain loyal customers; however there are a growing number of researchers that question the validity of loyalty programmes. Gomez, Arranz and Cillan (2006) are of the opinion that in the case of grocery retail consumers that loyalty programmes do not modify the behaviour of these consumers. Cigliano, Georgiadis, Pleasance and Whalley indicated that loyalty programme members do not necessarily change their behaviour; they simply take the rewards offered for their current behaviour and move on, while Shugan (2005) criticises loyalty programmes for mainly rewarding the decision makers and not really the payers.

Another concern raised is that loyalty programmes can harm the reputation of the company or brand as customers can question the validity of the retailers core principles like price and quality (Cigliano et al 2000). Dowling and Uncles (1997) may have a more valid observation when they argue that in a competitive environment, a successful loyalty programme will quickly be copied by competitors who will then attract the same customers back to their organisation - implying no or little advantage for the company except additional costs to launch such a programme. Benavent, Meyer-Waarden and Crie highlight the basic inefficiencies of allocating additional resources (and often discounts) to customers who can already be regarded as good customers, since these 'good customers' are typically the ones who join the loyalty programme in the first place. The net effect is that organisations are spending money on customers who are already displaying loyal behaviour and not on those who may be more easily tempted by competitive offerings. The critique against loyalty programmes is not unfounded. Many authors also talk of polygamous loyalty which implies that customers are members of more than one loyalty programme, often at competing retailers (Berman 2006; Van der Spuy 2011); implying that their so-called loyalty is being spread across more than one supplier. The existence of polygamous loyalty one again focuses the attention on the effectiveness of loyalty programmes. 
The majority of marketing literature supports the use of loyalty programmes to improve customer commitment to the organisation; to improve the likelihood of repurchase from the organisation and to encourage consumers to recommend the organisation to friends and colleagues. These assertions lead to the researchers formulating the following hypotheses with regards to the results of loyalty programme membership:

$\mathbf{H}_{1}$ : $\quad$ Members of loyalty programmes are more committed to the organisation than non-members.

$\mathbf{H}_{2}$ : $\quad$ Members of loyalty programmes purchase more from the organisation than non-members.

$\mathbf{H}_{3}$ : Members of loyalty programmes will recommend the organisation to friends and colleagues.

$\mathbf{H}_{4}$ : $\quad$ Members of loyalty programmes will purchase more from the organisation in the future

\section{METHODOLOGY}

The apparel industry in South Africa comprising the sales of both clothing and footwear represents yearly sales of R 151454.8 million (2011 figures) (Anon2 2012). The South African apparel retail market consists of five big retailers who jointly represent $38.5 \%$ of the total annual turnover. This study focussed on one particular clothing retailer in Gauteng, who on its own represents $20.3 \%$ of the market, making it the largest clothing retailer in SA. The retailer was therefore selected owing to its stature as the largest clothing retailer in South Africa and also the unique nature of its customer base which consist of three distinct groups of customers - 'cash only' customers, loyalty programme members who also pay cash and credit customers who purchase on terms. For reasons of confidentiality, the retailer will be referred to as RetailerX in this article.

A total of 308 shoppers at various shopping malls in the Gauteng province in South Africa were included in the survey. Convenience sampling, which is a method of sampling where the sample is selected at the convenience of the researcher (Hair, Bush and Ortinau 2004), was used to identify shopping malls based on their availability for research (some shopping malls do not allow research to be conducted on their premises), their geographic location (the study was limited to Gauteng) and their demographic representation of customers (malls were selected based on their representation of the various Living Standards Measure (LSM) groups in order to obtain a even spread of customers from all LSM groups). The Living Standards Measure (LSM) is an index developed by the South African Advertising Research Foundation (SAARF) to segment the South African population according to 29 lifestyle variables such as 'having access to electricity', 'owning a vehicle' and 'having access to digital satellite television'. LSM is the most widely used marketing research tool in Southern Africa (Anon3 2012). Individual respondents were selected by the fieldworkers who conducted mall-intercept interviews.

Of the 308 shoppers interviewed, a total of 103 were members of the loyalty programme and 101 were not members. The remaining 104 respondents purchased using credit facilities. The questionnaire used for this study was a structured questionnaire consisting of 18 individual questions with subsections. The questionnaire was formulated based on the literature study, and included elements designed to measure the respondents' emotional attachment to the retailer and their current and future behavioural intentions. These groupings are indicated below in order to provide a clear distinction between the elements that were researched as each measured specific issues related to the respondents views. Each of the applicable questionnaire design elements is briefly shown below:

\section{Emotional attachment to the organisation}

Emotional attachment to the retailer was measured using a five point Likert scale. Respondents were asked to indicate if they strongly agreed, agreed, neither agreed nor disagreed, disagreed or strongly disagreed with the following statements:

\begin{tabular}{l|l}
1.1 & I am very committed to RetailerX
\end{tabular}

1.2 It would matter a lot to me if I could not buy from RetailerX

\section{Current and future behavioural intentions}

Responses were recorded using a five point Likert scale in order to indicate the degree of agreement with the following statements: 


\begin{tabular}{|l|l|}
\hline 2.1 & I buy most of my clothes from RetailerX \\
\hline 2.2 & I would recommend RetailerX to my friends \\
\hline 2.3 & I am likely to buy even more of my clothes from RetailerX in the future \\
\hline 2.4 & I am likely to continue to use RetailerX as one of the stores I purchase from \\
\hline
\end{tabular}

The literature study emphasised the importance and purpose of loyalty programmes for retailers to create and maintain loyal customer behaviour. A total of 204 respondents qualified as either cash only buyers or loyalty programme members; credit customers were not included in the analysis owing to their perceived lack of freedom to change suppliers at will.

The proposed hypotheses were tested using nonparametric, independent sample tests. For the purposes of this study, members of the loyalty programme were the first independent sample, while non-members formed the second.

\section{MAIN FINDINGS OF THE RESEARCH}

The descriptive statistical results of the study are represented in Table 1.1

Table 1.1 Mean scores for members and non-members

\begin{tabular}{|c|c|c|}
\hline Statement & $\begin{array}{c}\text { Non-members } \\
\text { Mean scores }\end{array}$ & $\begin{array}{c}\text { Members } \\
\text { Mean scores }\end{array}$ \\
\hline I am very committed to RetailerX & 3.42 & 3.73 \\
\hline It would matter a lot to me if I could not buy from RetailerX & 3.43 & 3.50 \\
\hline I buy most of my clothes from RetailerX & 3.18 & 3.46 \\
\hline I would recommend RetailerX to my friends & 4.10 & 4.21 \\
\hline I am likely to buy even more clothes from RetailerX & 3.84 & 3.94 \\
\hline I am likely to continue to use RetailerX as one of the stores I purchase from & 4.04 & 4.09 \\
\hline
\end{tabular}

From the descriptive statistics presented in Table 1.1, it is clear that members of the loyalty programme have higher mean scores than non-members for each of the questions. This implies that on average, loyalty programme members report being more committed to the retailer; are more concerned about not being able to purchase from the retailer in the future; buy most of their clothes from the retailer; would recommend the retailer to their friends and are likely to buy even more clothes from the retailer in the future and are likely to continue to use the retailer as one of the stores that they purchase from. The descriptive statistics appear to support the literature by demonstrating that members of loyalty programmes do in fact demonstrate more loyal behaviour than non-members as indicated in Figure 1.1.

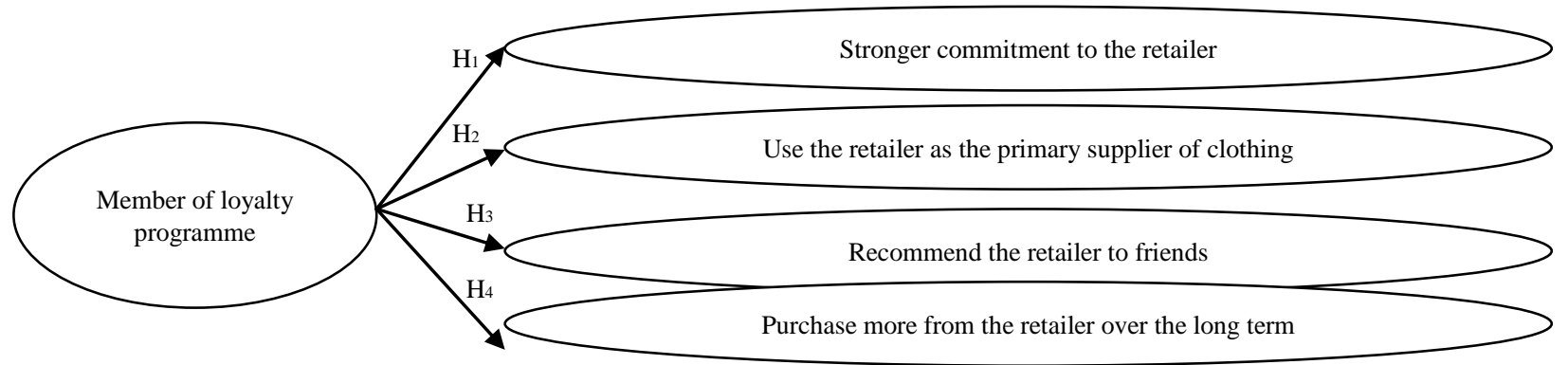

Figure 1.1 Hypothesised relationships between membership status and loyal behaviour

Figure 1.1 illustrates that being a member of a loyalty programme will result in stronger commitment to the retailer $\left(\mathrm{H}_{1}\right)$; the member will use the retailer as the primary source of clothing $\left(\mathrm{H}_{2}\right)$; the member will recommend the retailer to their friends $\left(\mathrm{H}_{3}\right)$; and the member will purchase more from the retailer in the future $\left(\mathrm{H}_{4}\right)$. In order to test the significance of these results and to attempt to draw valid conclusions from the data, non-parametric MannWhitney tests were conducted to accept or reject the hypotheses as stated. The Mann-Whitney tests ranks are presented in Table 1.2. 
Table 1.2 Mann-Whitney test ranks

\begin{tabular}{|c|c|c|c|c|}
\hline Statement & & $\mathbf{N}$ & Mean Rank & $\begin{array}{l}\text { Sum of } \\
\text { Ranks }\end{array}$ \\
\hline \multirow[t]{3}{*}{ I am very committed to RetailerX } & Members & 103 & 109.33 & 11261.50 \\
\hline & Non-members & 101 & 95.53 & 9648.50 \\
\hline & Total & 204 & & \\
\hline \multirow[t]{3}{*}{ It would matter a lot to me if I could not buy from RetailerX } & Members & 102 & 103.98 & 10605.50 \\
\hline & Non-members & 101 & 100.00 & 10100.50 \\
\hline & Total & 203 & & \\
\hline \multirow[t]{3}{*}{ I buy most of my clothes from RetailerX } & Members & 102 & 109.28 & 11147.00 \\
\hline & Non-members & 101 & 94.64 & 9559.00 \\
\hline & Total & 203 & & \\
\hline \multirow[t]{3}{*}{ I would recommend RetailerX to my friends } & Members & 103 & 106.95 & 11015.50 \\
\hline & Non-members & 101 & 97.97 & 9894.50 \\
\hline & Total & 204 & & \\
\hline \multirow[t]{3}{*}{ I am likely to buy even more clothes from RetailerX } & Members & 103 & 106.06 & 10924.00 \\
\hline & Non-members & 101 & 98.87 & 9986.00 \\
\hline & Total & 204 & & \\
\hline \multirow[t]{3}{*}{$\begin{array}{l}\text { I am likely to continue to use RetailerX as one of the stores I } \\
\text { purchase from }\end{array}$} & Members & 103 & 103.93 & 10705.00 \\
\hline & Non-members & 100 & 100.01 & 10001.00 \\
\hline & Total & 203 & & \\
\hline
\end{tabular}

Table 1.2 supports the descriptive statistics by reinforcing the fact that members have higher mean rank scores than non-members. It can be seen for example that the members' ranked mean when it comes to being committed to the retailer is 109.33 while non-members' ranked mean is only 95.53 again implying that members perceive themselves to much more committed to the retailer than non-members. The Mann-Whitney test statistics, as presented in table 1.3 tell a different story.

Table 1.3 Mann-Whitney test statistics

\begin{tabular}{|c|c|c|c|c|c|c|}
\hline & $\begin{array}{l}\text { I am very } \\
\text { committed to } \\
\text { RetailerX }\end{array}$ & $\begin{array}{c}\text { It would } \\
\text { matter a lot to } \\
\text { me if I could } \\
\text { not buy from } \\
\text { RetailerX }\end{array}$ & $\begin{array}{c}\text { I buy most of } \\
\text { my clothes } \\
\text { from } \\
\text { RetailerX }\end{array}$ & $\begin{array}{c}\text { I would } \\
\text { recommend } \\
\text { RetailerX to } \\
\text { my friends }\end{array}$ & $\begin{array}{c}\text { I am likely to } \\
\text { buy even } \\
\text { more clothes } \\
\text { from } \\
\text { RetailerX }\end{array}$ & $\begin{array}{l}\text { I am likely to } \\
\text { continue to } \\
\text { use RetailerX } \\
\text { as one of the } \\
\text { stores I } \\
\text { purchase from }\end{array}$ \\
\hline Mann-Whitney U & 4497.500 & 4949.500 & 4408.000 & 4743.500 & 4835.000 & 4951.000 \\
\hline Wilcoxon W & 9648.500 & 10100.500 & 9559.000 & 9894.500 & 9986.000 & 10001.000 \\
\hline $\mathbf{Z}$ & -1.750 & -.497 & -1.838 & -1.204 & -.933 & -.539 \\
\hline $\begin{array}{l}\text { Asymp. Sig. } \\
\text { (2-tailed) }\end{array}$ & .080 & .620 & .066 & .229 & .351 & .590 \\
\hline
\end{tabular}

It can be seen from Table 1.3 that only two of the six variables are significantly related to the membership status, namely variable 1.1 (I am very committed to RetailerX) ( $\mathrm{p}=0.080$ ) and variable 2.1 (I buy most of my clothes from RetailerX) ( $\mathrm{p}=0.066)$ at an acceptable confidence level of $90 \%$. It is therefore concluded that $\mathrm{H}_{1}$ and $\mathrm{H}_{2}$ can be accepted meaning that there is a significant relationship between being a member of the loyalty programme and the level of perceived commitment to the retailer; and that there is a significant relationship between being a member of a loyalty programme and purchasing more clothing from the retailer. $\mathrm{H}_{3}$ and $\mathrm{H}_{4}$ cannot be supported by the data and must therefore be rejected. Significant relationships are indicated in Figure 1.2. 


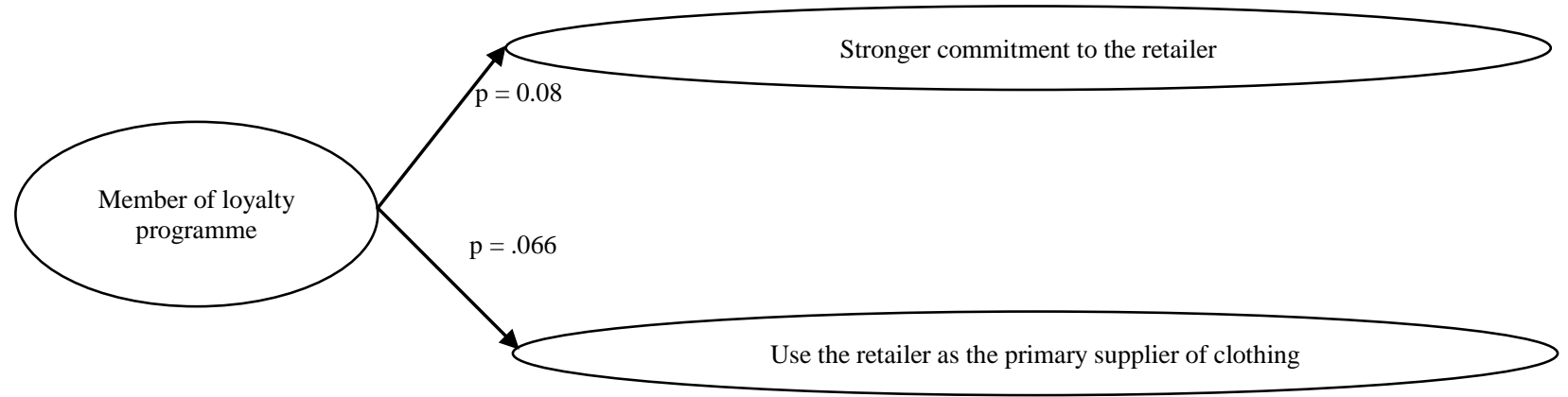

Figure 1.2 Significant relationships between membership status and loyal behaviour

The research reveals no significant relationship between membership of the loyalty programme and recommendation of the retailer $\left(\mathrm{H}_{3}\right)$ or potential for future purchases from the retailer $\left(\mathrm{H}_{4}\right)$. Correlation analysis between all seven variables (the six statements and membership status) revealed a different set of interactions between the variables. Non-parametric correlation analysis using Spearman's rho results are indicated in Table 1.4.

Table 1.4 Correlation analysis results

\begin{tabular}{|c|c|c|c|c|c|c|c|c|}
\hline Statement & $\begin{array}{l}\text { Spearman's } \\
\text { rho }\end{array}$ & $\begin{array}{l}\text { Membership } \\
\text { status }\end{array}$ & $\begin{array}{l}\text { Var } \\
1.1\end{array}$ & $\begin{array}{l}\text { Var } \\
1.2\end{array}$ & $\begin{array}{l}\text { Var } \\
2.1\end{array}$ & $\begin{array}{l}\text { Var } \\
2.2\end{array}$ & $\begin{array}{l}\text { Var } \\
2.3\end{array}$ & $\begin{array}{l}\text { Var } \\
2.4\end{array}$ \\
\hline \multirow[t]{3}{*}{ Method of payment } & $\begin{array}{l}\text { Correlation } \\
\text { Coefficient }\end{array}$ & 1.000 & & & & & & \\
\hline & Sig. (2-tailed) & - & & & & & & \\
\hline & $\mathrm{N}$ & 204 & & & & & & \\
\hline \multirow[t]{3}{*}{ I am very committed to RetailerX } & $\begin{array}{l}\text { Correlation } \\
\text { Coefficient }\end{array}$ & -.123 & 1.000 & & & & & \\
\hline & Sig. (2-tailed) & .080 & - & & & & & \\
\hline & $\mathrm{N}$ & 204 & 204 & & & & & \\
\hline \multirow[t]{3}{*}{$\begin{array}{l}\text { It would matter a lot to me if I } \\
\text { could not buy from RetailerX }\end{array}$} & $\begin{array}{l}\text { Correlation } \\
\text { Coefficient }\end{array}$ & -.035 & $.549^{* * *}$ & 1.000 & & & & \\
\hline & Sig. (2-tailed) & .621 & .000 & - & & & & \\
\hline & $\mathrm{N}$ & 203 & 203 & 203 & & & & \\
\hline \multirow[t]{3}{*}{$\begin{array}{l}\text { I buy most of my clothes from } \\
\text { RetailerX }\end{array}$} & $\begin{array}{l}\text { Correlation } \\
\text { Coefficient }\end{array}$ & -.129 & $.593^{* *}$ & $.508^{* *}$ & 1.000 & & & \\
\hline & Sig. (2-tailed) & .066 & .000 & .000 & - & & & \\
\hline & $\mathrm{N}$ & 203 & 203 & 203 & 203 & & & \\
\hline \multirow[t]{3}{*}{$\begin{array}{l}\text { I would recommend RetailerX to } \\
\text { my friends }\end{array}$} & $\begin{array}{l}\text { Correlation } \\
\text { Coefficient }\end{array}$ & -.084 & $.431^{* *}$ & $.409^{* *}$ & $.455^{* *}$ & 1.000 & & \\
\hline & Sig. (2-tailed) & .230 & .000 & .000 & .000 & - & & \\
\hline & $\mathrm{N}$ & 204 & 204 & 203 & 203 & 204 & & \\
\hline \multirow[t]{3}{*}{$\begin{array}{l}\text { I am likely to buy even more } \\
\text { clothes from RetailerX }\end{array}$} & $\begin{array}{l}\text { Correlation } \\
\text { Coefficient }\end{array}$ & -.065 & $.609^{* * *}$ & $.439^{* *}$ & $.633^{* *}$ & $.680^{* *}$ & 1.000 & \\
\hline & Sig. (2-tailed) & .352 & .000 & .000 & .000 & .000 & - & \\
\hline & $\mathrm{N}$ & 204 & 204 & 203 & 203 & 204 & 204 & \\
\hline \multirow[t]{3}{*}{$\begin{array}{l}\text { I am likely to continue to use } \\
\text { RetailerX as one of the stores I } \\
\text { purchase from }\end{array}$} & $\begin{array}{l}\text { Correlation } \\
\text { Coefficient }\end{array}$ & -.038 & $.371^{* *}$ & $.244^{* *}$ & $.414^{* *}$ & $.397^{* *}$ & $.480^{* *}$ & 1.000 \\
\hline & Sig. (2-tailed) & .591 & .000 & .000 & .000 & .000 & .000 & - \\
\hline & $\mathrm{N}$ & 203 & 203 & 202 & 202 & 203 & 203 & 203 \\
\hline
\end{tabular}

The correlation analysis results depicted in table 1.4 highlight the fact that there is a significant positive correlation between variable 1.1 (being committed to the retailer) and all other variables, regardless of membership status. This implies that the customers who are displaying loyal behaviour are those customers who perceive themselves to be committed to the retailer and not only those who are members of the loyalty programme. This 
requires a redesign of Figure 1.1 to illustrate the relationship between being a member of a loyalty programme and loyal behaviour to include the additional component of commitment. The revised hypothesised relationship is presented in Figure 1.3.

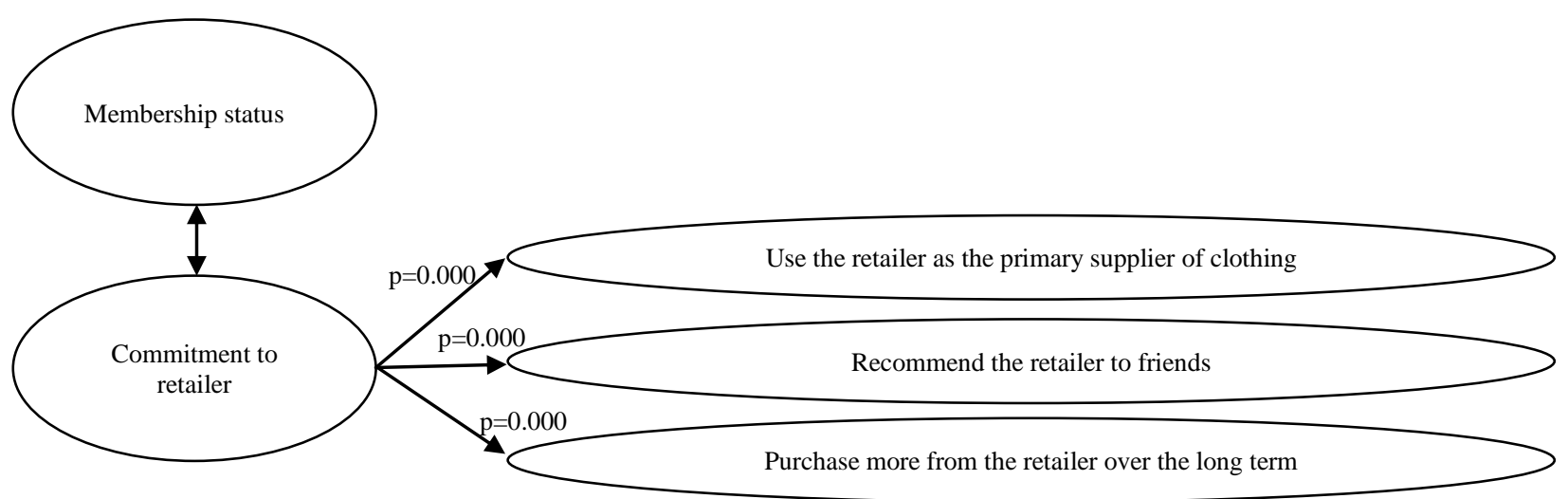

Figure 1.3 Hypothesised relationships between membership status and loyal behaviour

The relationships illustrated in figure 1.3 can be summarised as follows:

1. There is a significant correlation between membership status and commitment to the retailer. It is unclear if loyalty programme members become committed to the retailer or if committed customers become members of the loyalty programme. The direction of this relationship requires additional research and is beyond the scope of this article. The uncertain nature of this relationship could provide support to Benavent, MeyerWaarden and Crie's argument that organisations are spending money on customers who are already committed to the organisation.

2. There is a significant positive relationship between customers' levels of commitment to the retailer and their use of the retailer as primary source of clothing supply. Committed customers will buy more from the retailer.

3. There is a significant positive relationship between the customers' levels of commitment to the retailer and their willingness to recommend the retailer to their friends. Committed customers will advocate the organisation to their friends and in doing so become cost-effective marketing tools for the organisation.

4. There is a significant positive relationship between the customers' levels of commitment to the retailer and their willingness to purchase more from the retailer over the long-term and also to include the retailer in their consideration set for clothing purchases.

\section{MANAGERIAL IMPLICATIONS}

The results of this study are of importance to retailers as it can be concluded that while members of loyalty programmes may purchase most of their clothes from that retailer and be more emotionally committed to the retailer, these customers do not display signs of being any more loyal to that particular retailer over the long term when compared to non-members. These customers are generally not prepared to place their own reputations on the line by recommending the retailer to friends nor would they in any way be bothered if they could no longer buy from the retailer. They also do not indicate any likelihood of buying even more clothes from this retailer in the future. The significant relationship between commitment to the retailer and the desired loyal behaviour such as recommendation and potential future purchases needs to be borne in mind when retailers consider the use of a loyalty programme. Given these findings it is clear that the objectives of the retail loyalty programme are the most important consideration that retailers must take into account when introducing a new loyalty programme or deciding on the future of their current programme. Loyalty programmes designed to create or encourage loyal behaviour may only do so indirectly as a function of commitment to the retailer and could very possibly be reliant on attracting only members who are already committed to the retailer. While the possibility exists that loyalty programmes are encouraging commitment from members and thereby motivating loyal behaviour, the results of this study do not support that conclusion and further research is necessary into the sequence of the membership-commitment 
relationship. If the objective of the loyalty programme is to create and maintain sales over the long term, the results of this study indicate that non-members are just as likely to return to purchase even more from the retailer in the future than members. If the objectives of the programme are to gather customer data, then the long-term behavioural effects of the members are not really relevant and the value of the data gathered must be weighed up against the cost of the programme.

It is suggested that minor tweaks to loyalty programmes could result in loyal behaviour. Programmes that are designed to encourage commitment utilising special treatment benefits and not just monetary rewards may motivate customers to be more emotionally connected to the retailer and could encourage peer advocacy.

\section{AUTHOR INFORMATION}

Michael Noel du Toit, Lecturer in Marketing Management, Department of Marketing and Retail Management, University of South Africa. Pretoria. Tel: +27-12429 4453. E-mail: Dtoitm3@unisa.ac.za (Corresponding author)

Michael Colin Cant, Professor in Marketing Management, Department of Marketing and Retail Management, University of South Africa. Pretoria. Tel: +27-12429 4456. E-mail: cantmc@unisa.ac.za

\section{REFERENCES}

1. Allaway, A.W., Gooner, R.M., Berkowitz, D. and Davis, L. 2006. "Deriving and exploring behaviour segments within a retail loyalty card program". European Journal of Marketing, 40(11/12): 1317-1339.

2. Anon1. 2012. The Many advantages of having a loyalty program. [Online] Available from: http://hostingdomainmurah.com/the-many-advantages-of-having-a-loyalty-program/ [Accessed: 27/07/2012].

3. Anon2. 2012. Passport. Apparel in South Africa. Euromonitor International.

4. Anon3. 2012. South African Advertising Research Foundation. [Online] Available from: http://www.saarf.co.za [Accessed: 15/06/2012].

5. Anon4. 2007. "Tesco leads the way in the loyalty program stakes". Strategic Direction 23(2): 18-21.

6. Banasiewicz, “A. 2005. Loyalty program planning and analytic”. Journal of Consumer Marketing 22(6): 332-339.

7. Benavent, C., Meyer-Waarden, L. and Crie, D. Analysis of the efficiency of loyalty programs: a case study. [Online] Available from: http://christophe.benavent.free.fr/publications/Cards.PDF [Accessed on 06/08/2012].

8. Berman, B. 2006. "Developing an effective customer loyalty program." California Management Review, 49(1): 123-148.

9. Blasberg, J., Vishwanath, V. and Allen, J. 2008. "Tools for converting consumers into advocates". Strategy and Leadership, 36(2): 16-23.

10. Capizzi, M., Ferguson, R. and Cuthbertson, R. 2004. "Loyalty trends for the $21^{\text {st }}$ century". Journal of Targeting, Measurement and analysis for Marketing 12(3): 199-212.

11. Cigliano, J., Georgiadis, M., Pleasance, D. and Whalley, S. 2000. "The power of loyalty creating winning retail loyalty programs". McKinsey on Retail. McKinsey \& Company.

12. Dowling, G.R. and Uncles, M. 1997. "Do customer loyalty programs really work?" Sloan Management Review, 38(4):71-82.

13. Gomez, B.G., Arranz, A.G. and Cillan, J.G. 2006. "The role of loyalty programs in behavioural and affective loyalty". Journal of Consumer Marketing, 23(7): 387-396.

14. Griffin, J. 2002. Customer loyalty. How to earn it and keep it. San Francisco: Jossey-Bass.

15. Hair, J.F., Bush, P.R. and Ortinau, D. 2003. Marketing research. $2^{\text {nd }}$ ed. McGraw-Hill Irwin.

16. Hallberg, G. 2004. "Is your loyalty programme really building loyalty? Why increasing emotional attachment, not just repeat buying, is key to maximising programme success". Journal of Targeting, Measurement and Analysis for Marketing, 12(3): 231-241.

17. Keiningham, T., Aksoy, L., Cooil, B. and Andreassen, T. 2008. "Linking Customer Loyalty to Growth". MIT Sloan Management Review 2008: 51-57.

18. Kumar, V. 2006. CLV: “The Databased Approach”. Journal of Relationship Marketing, 5(2/3): 7-35. 
19. Malhotra, N.K. 2010. Marketing research. An applied orientation. $6^{\text {th }}$ ed. New Jersey: Pearson Prentice Hall.

20. Oxford Dictionaries Online. 2012. [Online] Available from: http://oxforddictionaries.com/[Accessed on 17/06/2012].

21. Polevoi, L. 2012. How customer loyalty programs can bring you more business. [Online] Available from: http://blog.intuit.com/marketing/how-customer-loyalty-programs-can-bring-you-more-business/ [Accessed on 27/07/2012)].

22. Reichheld, F. 2006. The ultimate question: driving good profits and true growth. Boston: Harvard Business School Publishing Corporation.

23. Shugan, S.M. 2005. "Brand Loyalty Programs: Are They Shams?" Marketing Science, 24(2): 185-193.

24. Sisolak, P. 2012. Participating in supermarket loyalty programs means giving up privacy. [Online] Availabe from: http://www.gobankingrates.com/savings-account/participating-supermarket-loyaltyprograms-mean-giving-up-privacy/ [Accessed 27/07/2012)].

25. Steffes, E.M and Burgee, L.E. 2009. "Social ties and online word of mouth". Internet Research, 19(1): 4259.

26. Wu, L., Hai-Chen and Chung-Yu, W. 2012. Customer responses to loyalty programs. Business and Information (Sapporo, July 2-5): B1-B18.

27. Yi, Y. and Jeon, H. 2003. "Effects of Loyalty Programs on Value Perception, Program Loyalty, and Brand Loyalty". Journal of the Academy of Marketing Science, 31(3): 229-240.

28. Zikmund, W.G., Babin, B.J., Carr, J.C. and Griffin, M. 2010. Business research methods. $8^{\text {th }}$ ed. Canada: South-Western Cenage Learning. 
NOTES 